\title{
Comparative analysis of the functional characteristics and motor qualities of students of different generations and body types
}

\author{
Kolokoltsev M.M. ${ }^{1 \mathrm{ABCDE}}$, Iermakov S.S. ${ }^{2 \mathrm{ABCDE}}$, Jagiello M. ${ }^{3 \mathrm{ABCDE}}$ \\ ${ }^{1}$ Department of the Physical Culture, Irkutsk National Research Technical University, Russia \\ ${ }^{2}$ Department of Tourism and Recreation, Gdansk University of Physical Education and Sport, Poland \\ ${ }^{3}$ Department of Theory of Sport and Human Motority, Gdansk University of Physical Education and Sport, Poland
}

Authors' Contribution: A - Study design; B - Data collection; C - Statistical analysis; D - Manuscript Preparation; E - Funds Collection.

\begin{abstract}
Purpose: $\quad$ the comparative analysis of screening studies of physical fitness and functional condition of young men with different body types (the territory of Baikal region, Russia; the interval of the study is 10 years).

Material: $\quad$ First-year students (age 17-18 years; $n=1003$; in $2008-n=523$; in $2017-n=480$ ) of Irkutsk National Research Technical University (Pribaikalye, Russia) participated into the research. All students are classified for health reasons to the main medical group (no deviations in health status). All students attended classes in the discipline "Physical Education". It was done the comparative analysis of motor skills; physiometric indicators; the content of muscle, fat and bone mass.

Results: It was revealed the significant differences $(p<0,05)$ in the values of the motor test indicators. It was determined "leading" and "lagging" motor qualities of young men with different body types. It was defined decrease of indicators' values in motor tests in young men in 2017, in comparison with the results of the survey in 2008. The decrease in the values of motor test indicators is more frequently revealed in young men of hypersthenic group (examined in 2017), in comparison with normosthenics and asthenics. There is a deterioration in the majority of the functional characteristics of young men bodies (in 2017) in comparison with 2008 data.

Conclusions: $\quad$ University professors (of the discipline - "Physical Education") should form a predictive database of screening observations on the development of morphofunctional and motor qualities of students with different body types. This will allow to correct the educational process on the physical education of students applying the integrative pedagogical methods and teaching methods.

Keywords: physical education, students, physical condition, somatotyping, component body type.
\end{abstract}

\section{Introduction}

The main parameters of the physical health of a person are the functional characteristics of the body and it's motor abilities to perform physical activities [1,2]. The study of the cardiovascular system condition allows to assess the person's reserve capacity for physical training and sports $[3,4]$. It also helps to determine the dependence of the vegetative regulation of blood circulation on the level of physical fitness of the body $[5,6]$. The decrease in physical fitness $[7,8]$ and the functional indicators of modern youth in Russia is studied in the recent researches $[9,10]$. There is an increase in deviations from the norm in the cardiovascular, respiratory, and immune systems of the body $[11,12]$. It is considered that this is correlated with a violation of the adaptive capacity of the person [1315]. The significant decrease in functionality is observed in regions of anthropogenic impact [16].

One of the reasons for the deterioration of the physical health of the population is low physical activity. Significant hypodynamia is registered in Europeans [17, 18], in the USA [19], Moldova [20, 21], in Russia [22, 23]. Other studies determined:

- Approximately $27 \%$ of high school students meet the aerobic component of the pediatric guidelines (60 minutes of daily moderate-to-vigorous activity), and the proportion of youth meeting the guidelines decreases with advancing age [24];

(c) Kolokoltsev M.M., Iermakov S.S., Jagiello M., 2018

doi:10.15561/18189172.2018.0602
- A pilot randomized trial assessed the feasibility and effectiveness of an intervention combining Smartcare (activity tracker with a smartphone application) and financial incentives. The addition of financial incentives to Smartcare was effective in increasing physical activity and reducing obesity [25];

- Expansion of students' physical activity increases the results in motor tests [26].

It is known that the peculiarities of morphofunctional status depend on the type of human body [27]. It was performed studies of motor qualities characteristics in students with various somatotype groups [28, 29]. It is shown that representatives of the microsomatotypes have advantages over the macrosomatotype bodies in such motor qualities as speed; muscle strength of the upper limbs; coordination abilities; general endurance. The screening somatotyping of technical university students was performed in 2007-2008 (Irkutsk, Russia). It was applied the method of determining the overall, component and proportional level of variation [30, 31]. It was determined the expressed differences in the motor qualities of students with different somatotypes.

The determination of body type characteristics of youth allows researchers to recommend the best option for constructing an educational process on physical education in universities $[32,33]$; the training process in athletes [34-36]; physical training of military personnel [37].

Changes in the living conditions and lifestyle of modern youth are reflected in the level of their physical 
health, in comparison with previous generations [1].

It is relevant to perform a comparative analysis of changes in the motor qualities of the youth of different generations with a significant time interval. The comparative analysis of the functional characteristics and motor qualities of students with different body types was not performed at the urbanized territories of Baikal region (Russia) [38, 39].

Hypothesis. The authors suggest that data on the comparative features of the motor qualities and functional body characteristics of students of different generations can be applied in the field of demography, medicine, pedagogy, sociology, and physical culture. Such an approach will allow to correct curricula of physical education in universities.

The purpose of the research is to perform a comparative analysis of screening studies of physical fitness and functional condition of young men with different body types on the territory of Baikal region (Russia (the study interval is 10 years).

\section{Material and methods.}

Participants. The first year students (age 17-18 years; $\mathrm{n}=1003$; in $2008-\mathrm{n}=523$; in $2017-\mathrm{n}=480$ ) of Irkutsk National Research Technical University (Pribaikalye, Russia) were examined. All the young men were natives of an urbanized city with a significant negative environmental background. All students are classified for health reasons to the main medical group (no deviations in health status). All students attended classes in the discipline "Physical Education". The performed research does not impair the rights and does not endanger the wellbeing of students in accordance with ethical standards (WMA Declaration of Helsinki, 2008 [40]).

Design of the study. The pedagogical screening of motor test indicators and the functional condition of students with different body types was performed at physical education classes at the beginning of the study year (in 2008 and in 2017). It was measured body length and chest circumference [41]. It was applied M.V. Chernorutsky's scheme with the calculation of Pigne index according to the formula:

$$
\text { (I) }=\mathrm{L}-(\mathrm{P}+\mathrm{T}) \text {, }
$$

where $\mathrm{L}-$ is the standing body length $(\mathrm{cm}), \mathrm{P}-$ is body weight $(\mathrm{kg}), \mathrm{T}-$ is chest circumference during expiration $(\mathrm{cm})$.

When the index was $<10$, the somatotype was assessed as hypersthenic $(\mathrm{H})$, in the interval of the index from 10 to 30 - as normosthenic (S) and $>30$ - as asthenic (A) [42].

The young men body types were determined by Matiegka's formulas [43] with the calculation of the absolute average value and percentage of fat, muscle and bone tissues. To characterize the correlations of the body types with the functional indicators were measured:

- heart rate before the load of 20 squats in $30 \mathrm{~s}$ (HR, $\mathrm{b} / 10 \mathrm{~s}$ );

- $\quad$ heart rate after 20 squats in $30 \mathrm{~s}(\mathrm{HR}, \mathrm{b} / 10 \mathrm{~s})$;

- $\quad$ heart rate recovery time ( $\mathrm{min}$ ) after 20 squats;

- $\quad$ systolic blood pressure (SBP), $\mathrm{mm} \mathrm{Hg}$;
- $\quad$ diastolic blood pressure (DBP), $\mathrm{mm} \mathrm{Hg}$;

- dynamometry of hands $(\mathrm{kg})$.

- The index of cardiovascular system reserve Robinson index (IRob = HRx: 100, c.u.) was applied [44] for the quantitative assessment of the energy potential of the human (SI = hand muscle strength / BM x $100 \%$ ) [45].

- The basic motor qualities of students were estimated. The following tests were applied:

- $\quad$ speed endurance and dexterity (10x5 shuttle test, sec);

- $\quad$ speed (100 m run, sec);

- $\quad$ speed-strength endurance of the flexor muscles of the body (Eurofit Sit Up Test (for $30 \mathrm{sec}$, quantity of times);

- $\quad$ strength and strength endurance of the muscles of the upper shoulder girdle (Pull-up bars, the quantity of times);

- the dynamic force of the muscles of the lower extremities (Standing Long Jump Test (Broad Jump), $\mathrm{cm})$

- $\quad$ active flexibility of the spine and hip joints (Seated Forward Bend, $\mathrm{cm}$ )

- $\quad$ general endurance (1000 m run, min, sec) [46, 47].

Statistical analysis. The software "StatSoft Statistica 6.1" and"Microsoft Excel" were applied to calculate the obtained data. The arithmetic mean of the indicators (M), the standard deviation $(\sigma)$ and the standard error $(\mathrm{m})$ were calculated. The assessment of the significance of differences in the mean values of independent samples was carried out by parametric methods using Student's t-test. Differences between the values of the indicators at the level of $\mathrm{p}<0.05$ were considered statistically significant.

\section{Results.}

The distribution of young men of different generations by somatotype is shown in Figure 1.

After 10 years, there is an increase in the number of young men hypersthenics in $8,5 \%$. The number of asthenics decreased in $6,03 \%$, and normosthenic in $2,48 \%$. These data indicate that the values of indicators of some motor tests in young men (2017) are reduced in comparison with the indicators of young men (2008).

In young men (2017), the decrease in the values of motor test indicators is recorded more frequently in the group of hypersthenics.

In 2017, there is a decrease in the values of indicators of the functional characteristics of young men in comparison with data of 2008 (Table 2).

\section{Discussion.}

The comparative analysis of screening surveys in 2008 and 2017 of young men with different body types revealed significant differences in the values of motor test indicators (Table 1). "Leading" and "lagging" motor qualities of students with different somatotypes are identified (Table 3 ).

It is determined that the priorities of motor qualities 


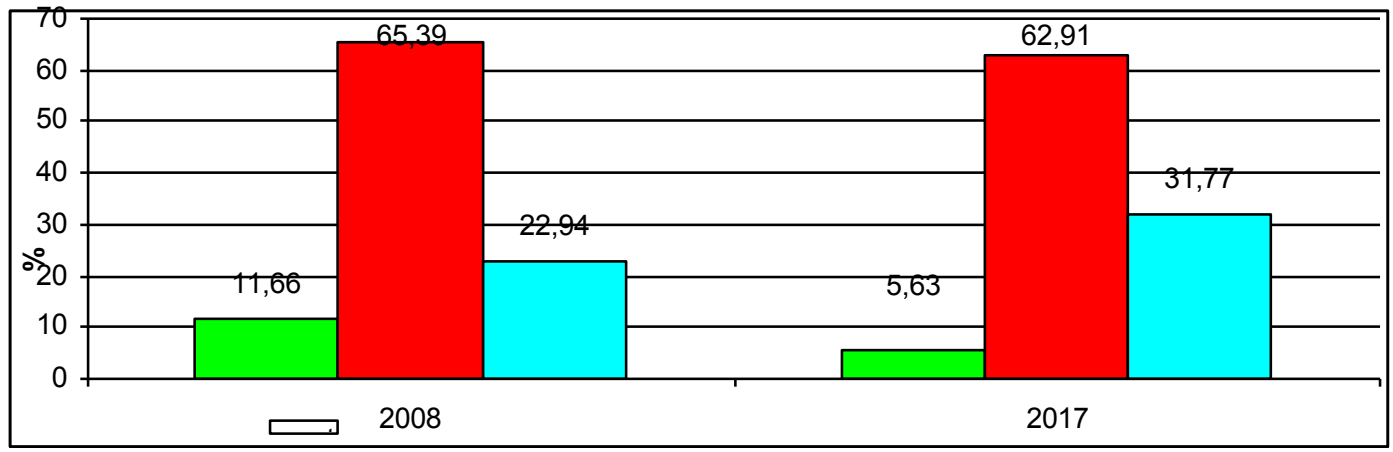

Fig. 1. The distribution of young men by somatotypes in 2008 and 2017 (in \%)

Table 1. Motor characteristics of young men with different body types, examined in 2008 and 2017. (M $\pm S D)$

\begin{tabular}{|c|c|c|c|c|c|c|c|c|}
\hline \multirow[b]{2}{*}{ Tests } & \multicolumn{4}{|l|}{2008 year } & \multicolumn{4}{|c|}{2017 year } \\
\hline & $\begin{array}{l}H \\
(n=120)\end{array}$ & $\begin{array}{l}N \\
(n=342)\end{array}$ & $A(n=61)$ & $P<0,05$ & $\begin{array}{l}H \\
(n=151)\end{array}$ & $\begin{array}{l}N \\
(n=302)\end{array}$ & $\begin{array}{l}A \\
(n=27)\end{array}$ & $P<0,05$ \\
\hline $\begin{array}{l}\text { 10x5 shuttle test, } \\
\text { sec }\end{array}$ & $\begin{array}{l}16,13 \pm \\
0,12\end{array}$ & $\begin{array}{l}15,79 \pm \\
0,05\end{array}$ & $\begin{array}{l}16,14 \pm \\
0,30\end{array}$ & $p_{1}-p_{2}$ & $\begin{array}{l}16,58 \pm \\
0,13 *\end{array}$ & $\begin{array}{l}16,16 \pm \\
0,09^{*}\end{array}$ & $\begin{array}{l}16,4 \pm \\
0,31\end{array}$ & $p_{1}-p_{2}$ \\
\hline 100 m run (sec) & $\begin{array}{l}14,33 \pm \\
0,10\end{array}$ & $\begin{array}{l}14,08 \pm \\
0,05\end{array}$ & $13,88 \pm 0,19$ & $\begin{array}{l}\mathrm{p}_{1}-\mathrm{p}_{2 ;} \\
\mathrm{p}_{1}-\mathrm{p}_{3}\end{array}$ & $\begin{array}{l}14,68 \pm \\
0,09 *\end{array}$ & $\begin{array}{l}14,14 \pm \\
0,04\end{array}$ & $\begin{array}{l}13,92 \pm \\
0,17\end{array}$ & $\begin{array}{l}p_{1}-p_{2} \\
p_{1}-p_{3}\end{array}$ \\
\hline $\begin{array}{l}\text { Pull-Up Bars, } \\
\text { quantity of times }\end{array}$ & $\begin{array}{l}12,6 \pm \\
0,49\end{array}$ & $\begin{array}{l}10,8 \pm \\
0,23\end{array}$ & $10,6 \pm 0,64$ & $\begin{array}{l}p_{1}-p_{2} \\
p_{1}-p_{3}\end{array}$ & $\begin{array}{l}10,2 \pm \\
0,31 *\end{array}$ & $\begin{array}{l}9,9 \pm \\
0,22\end{array}$ & $\begin{array}{l}10,0 \pm \\
0,66\end{array}$ & \\
\hline $\begin{array}{l}\text { Eurofit Sit Up } \\
\text { Test (for } 30 \mathrm{sec} \text { ), } \\
\text { quantity of times }\end{array}$ & $\begin{array}{l}29,8 \pm \\
0,40\end{array}$ & $\begin{array}{l}26,4 \pm \\
0,24\end{array}$ & $25,3 \pm 0,38$ & $\begin{array}{l}p_{1}-p_{2} \\
p_{1}-p_{3}\end{array}$ & $\begin{array}{l}26,1 \pm \\
0,37^{*}\end{array}$ & $\begin{array}{l}25,3 \pm \\
0,26^{*}\end{array}$ & $\begin{array}{l}25,5 \pm \\
0,85\end{array}$ & \\
\hline $\begin{array}{l}\text { Seated Forward } \\
\text { Bend, } \mathrm{cm}\end{array}$ & $\begin{array}{l}15,2 \pm \\
0,60\end{array}$ & $\begin{array}{l}15,7 \pm \\
0,37\end{array}$ & $14,1 \pm 0,87$ & & $\begin{array}{l}15,6 \pm \\
0,47\end{array}$ & $\begin{array}{l}15,3 \pm \\
0,34\end{array}$ & $\begin{array}{l}15,1 \pm \\
1,84\end{array}$ & \\
\hline $\begin{array}{l}\text { Standing Long } \\
\text { Jump Test (Broad } \\
\text { Jump), cm }\end{array}$ & $\begin{array}{l}233,5 \pm \\
1,53\end{array}$ & $\begin{array}{l}236,0 \pm \\
0,84\end{array}$ & $241,4 \pm 1,81$ & $p_{1}-p_{3}$ & $\begin{array}{l}225,7 \pm \\
1,51^{*}\end{array}$ & $\begin{array}{l}232,1 \pm \\
0,86\end{array}$ & $\begin{array}{l}237,8 \pm \\
3,18\end{array}$ & $\begin{array}{l}p_{1}-p_{2 ;} \\
p_{1}-p_{3}\end{array}$ \\
\hline $\begin{array}{l}1000 \mathrm{~m} \text { run (min, } \\
\mathrm{sec})\end{array}$ & $\begin{array}{l}3,58 \pm \\
0,02\end{array}$ & $\begin{array}{l}3,52 \pm \\
0,01\end{array}$ & $3,36 \pm 0,02$ & $\begin{array}{l}p_{1}-p_{2} \\
p_{1}-p_{3 ;} \\
p_{2}-p_{3}\end{array}$ & $\begin{array}{l}4,25 \pm \\
0,01 *\end{array}$ & $\begin{array}{l}3,58 \pm \\
0,01 *\end{array}$ & $\begin{array}{l}3,54 \pm \\
0,04 *\end{array}$ & $\begin{array}{l}p_{1}-p_{2} \\
p_{1}-p_{3}\end{array}$ \\
\hline
\end{tabular}

Note. $\mathrm{H}$ - hypersthenic; $\mathrm{N}$ - normosthenic; A - asthenic body types. ${ }^{*}$ - statistically significant differences between somatotypes in 2008 and $2017(p<0.05)$

in young men of different somatotypes and different generations didn't change. In correction of the educational process in physical education, it is necessary to include exercises directed on the development of lagging motor skills of students considering the somatotype.

In all young men (2008) with the hypersthenic body, the motor qualities (strength and strength endurance of the muscles of the upper shoulder girdle, speed-strength endurance of the flexor muscles of the body) are higher in comparison with other body types $(p<0,05)$. This is confirmed by studies by other authors [48].

According to our data, young men with asthenic somatotype $(p<0,05)$ had better indicators: speed, dynamic muscle strength of the lower limbs, and general endurance. This is consistent with studies devoted to the dependence of body mass on the body length [37]. We determined higher results in the main motor tests in girls with asthenic body type (with the exception of the strength of the muscles of the upper extremities) [33]. This indicates that the modern youth of the asthenic type of the constitution has a higher reserve capacity of physical condition in comparison with peers of other somatotypes.

There is no significant difference $(p>0,05)$ in the indicators of the motor tests for flexibility in young men. This is consistent with the results of the study of senior schoolchildren in Moscow (Russia) [48].

Indicators in the motor tests of students (2017) were lower than those of young men (2008) (Table 4).

The study of motor qualities among students of different populations in Bosnia and Herzegovina also showed a decline in performance in a number of motor tests [49].

The results of our research devoted to the content of muscle, fat and bone mass in the body structure of young men in Baikal region are presented in Fig. 2.

In young men hypersthenics (2008) the content of muscle body mass (MM) was $31,7 \pm 0,39 \mathrm{~kg}$. This indicator was in $6,9 \%$ higher than in normosthenics. 
Table 2. Functional characteristics of young men with different body types examined in 2008 and 2017. (M \pm SD)

\begin{tabular}{|c|c|c|c|c|c|c|}
\hline & $\mathbf{H}$ & & $\mathbf{N}$ & & A & \\
\hline Indicators & $\begin{array}{l}2008 \\
(n=120)\end{array}$ & $\begin{array}{l}2017 \\
(n=151)\end{array}$ & $\begin{array}{l}2008 \\
(n=342)\end{array}$ & $\begin{array}{l}2017 \\
(n=302)\end{array}$ & $\begin{array}{l}2008 \\
(n=61)\end{array}$ & $\begin{array}{l}2017 \\
(n=27)\end{array}$ \\
\hline Systolic blood pressure, $\mathrm{mm}$ & $114,5 \pm$ & $114,1 \pm$ & $113,9 \pm$ & $113,5 \pm$ & $111,2 \pm$ & $110,0 \pm$ \\
\hline $\mathrm{Hg}$ & 0,58 & 0,53 & 0,41 & 0,38 & 1,21 & 1,63 \\
\hline $\begin{array}{l}\text { Diastolic blood pressure, } \mathrm{mm} \\
\mathrm{Hg}\end{array}$ & $73,9 \pm 0,48$ & $74,2 \pm 0,45$ & $73,0 \pm 0,34$ & $72,5 \pm 0,33$ & $71,8 \pm 0,89$ & $72,3 \pm 0,98$ \\
\hline$H R, b / 10 s$ & $12,8 \pm 0,14$ & $\begin{array}{l}13,3 \pm 0,12 \\
*\end{array}$ & $12,2 \pm 0,04$ & $\begin{array}{l}12,7 \pm 0,05 \\
*\end{array}$ & $10,9 \pm 0,08$ & $\begin{array}{l}10,4 \pm 0,09 \\
*\end{array}$ \\
\hline $\begin{array}{l}\text { Heart rate recovery time } \\
\text { (min), b / } 10 \mathrm{~s}\end{array}$ & $19,7 \pm 0,14$ & $\begin{array}{l}20,8 \pm 0,15 \\
*\end{array}$ & $19,1 \pm 0,08$ & $\begin{array}{l}20,3 \pm 0,09 \\
*\end{array}$ & $18,3 \pm 0,19$ & $\begin{array}{l}17,2 \pm 0,33 \\
*\end{array}$ \\
\hline Heart rate recovery time (min) & $0,91 \pm 0,02$ & $\begin{array}{l}0,98 \pm 0,02 \\
*\end{array}$ & $0,88 \pm 0,01$ & $\begin{array}{l}0,93 \pm 0,01 \\
*\end{array}$ & $0,84 \pm 0,04$ & $\begin{array}{l}0,72 \pm 0,07 \\
*\end{array}$ \\
\hline Robinson index, c.u. & $87,9 \pm 0,82$ & $\begin{array}{l}91,5 \pm 0,52 \\
*\end{array}$ & $83,4 \pm 0,53$ & $\begin{array}{l}86,5 \pm 0,55 \\
*\end{array}$ & $73,2 \pm 0,94$ & $71,9 \pm 0,96$ \\
\hline Stroke volume, $\mathrm{ml}$ & $64,5 \pm 0,73$ & $64,1 \pm 0,47$ & $65,2 \pm 0,40$ & $65,6 \pm 0,42$ & $65,3 \pm 0,83$ & $64,1 \pm 0,85$ \\
\hline $\begin{array}{l}\text { Minute volume of blood } \\
\text { circulation, } \\
\mathrm{ml} / \mathrm{min}\end{array}$ & $\begin{array}{l}4953,6 \pm \\
43,2\end{array}$ & $4919 \pm 40,3$ & $\begin{array}{l}4772,6 \pm \\
31,1\end{array}$ & $\begin{array}{l}4801,9 \pm \\
33,5\end{array}$ & $\begin{array}{l}4270,7 \pm \\
72,4\end{array}$ & $\begin{array}{l}4192,1 \pm \\
84,2\end{array}$ \\
\hline Left hand dynamometry, kg & $44,5 \pm 0,72$ & $\begin{array}{l}41,8 \pm 0,37 \\
*\end{array}$ & $42,6 \pm 0,35$ & $\begin{array}{l}40,3 \pm 0,28 \\
*\end{array}$ & $41,9 \pm 0,73$ & $41,3 \pm 0,68$ \\
\hline Power index of left hand, \% & $57,4 \pm 0,76$ & $\begin{array}{l}55,5 \pm 0,42 \\
*\end{array}$ & $65,1 \pm 0,41$ & $\begin{array}{l}62,2 \pm \\
0,34 *\end{array}$ & $70,5 \pm 0,96$ & $70,6 \pm 0,95$ \\
\hline Right hand dynamometry, kg & $46,5 \pm 0,68$ & $\begin{array}{l}42,2 \pm 0,32 \\
*\end{array}$ & $44,7 \pm 0,35$ & $\begin{array}{l}41,5 \pm 0,31 \\
*\end{array}$ & $43,3 \pm 0,78$ & $42,6 \pm 0,72$ \\
\hline Power index of right hand, \% & $60,0 \pm 0,72$ & $\begin{array}{l}56,1 \pm 0,45 \\
*\end{array}$ & $68,3 \pm 0,43$ & $\begin{array}{l}64,1 \pm 0,40 \\
*\end{array}$ & $72,8 \pm 0,98$ & $72,8 \pm 1,10$ \\
\hline
\end{tabular}

Note. $\mathrm{H}$ is the hypersthenic body type, $\mathrm{S}$ is normosthenic body type, and $\mathrm{A}$ is the asthenic body type. * - statistically significant differences between somatotypes in 2008 and $2017(p<0.05)$

Table 3. Motor qualities priorities of young men of different generations with different body types from Baikal region

\begin{tabular}{|c|c|c|c|c|c|c|}
\hline \multirow{2}{*}{ Motor qualities } & \multicolumn{2}{|c|}{$\begin{array}{l}\text { Body types } \\
\text { H }\end{array}$} & \multicolumn{2}{|l|}{$\mathbf{N}$} & \multicolumn{2}{|l|}{ A } \\
\hline & 2008 & 2017 & 2008 & 2017 & 2008 & 2017 \\
\hline Speed endurance and dextrity & & lag & lead & lead & lag & \\
\hline $\begin{array}{l}\text { Speed } \\
\text { Strength and strength endurance of }\end{array}$ & lag & lag & & & lead & lead \\
\hline $\begin{array}{l}\text { the muscles of the upper shoulder } \\
\text { girdle }\end{array}$ & lead & lead & & lag & $\operatorname{lag}$ & \\
\hline $\begin{array}{l}\text { Speed strength endurance of flexor } \\
\text { muscles of the body }\end{array}$ & lead & lead & & lag & $\operatorname{lag}$ & \\
\hline Flexibility & & lead & lead & & $\operatorname{lag}$ & lag \\
\hline $\begin{array}{l}\text { Dynamic muscle strength of the } \\
\text { lower limbs }\end{array}$ & lag & lag & & & lead & lead \\
\hline General endurance & lag & $\operatorname{lag}$ & & & lead & lead \\
\hline
\end{tabular}

Note. $\mathrm{H}$ - hypersthenic; N - normosthenic; A - asthenic body types. "lead" - leading, "lag" - lagging motor qualities

Also in $11,04 \%$ more than in asthenics $(p<0.05)$. This difference provides an advantage in the power abilities of young men hypersthenics. A similar result was obtained in the city Magadan (Russia): higher indicators were determined in the back strength of young strong-built men [27].

Among young men (2008), with the lowest content of body fat mass (FM) was found in asthenics $(11,2 \pm 0,26$ $\mathrm{kg}$ ). This indicator is in $20.5 \%$ less than in normosthenics
$(13,5 \pm 0,17 \mathrm{~kg})$. This indicator is also less in $25,8 \%$ than in hypersthenics $(14,1 \pm 0,19 \mathrm{~kg})$. The maintenance of the bone mass of the body (BM) practically does not differ in young men with different body types. This is confirmed by authors' studies which didn't identify changes in bone mass in modern youths against the increase in fat and muscle mass [1, 50-52].

We found a decrease of $\mathrm{MM}$ in the young men bodies (2017) of all somatotypes $p<0.05$. In comparison 
Table 4. The decrease of indicators in motor tests in young men (2017) IN comparison with the results of tests in young men (2008) (in \%)

\begin{tabular}{|c|c|c|c|c|}
\hline \multirow{2}{*}{ Tests } & \multirow{2}{*}{ Motor qualities } & \multicolumn{3}{|c|}{ Decrease in \% } \\
\hline & & $\mathbf{H}$ & $\mathbf{N}$ & A \\
\hline $\begin{array}{l}\text { Standing Long Jump Test (Broad } \\
\text { Jump), cm }\end{array}$ & Speed endurance and dexterity & 2,8 & 2,3 & 0 \\
\hline $100 \mathrm{~m}$ run $(\mathrm{sec})$ & Rapidity & 2,4 & 0 & 0 \\
\hline Pull-Up Bars, quantity of times & $\begin{array}{l}\text { Strength and strength endurance of the muscles of } \\
\text { the upper shoulder girdle }\end{array}$ & 19,0 & 8,3 & 0 \\
\hline $\begin{array}{l}\text { Eurofit Sit Up Test (for } 30 \mathrm{sec} \text { ), } \\
\text { quantity of times }\end{array}$ & $\begin{array}{l}\text { Speed strength endurance of flexor muscles of the } \\
\text { trunk }\end{array}$ & 12,4 & 4,2 & 0 \\
\hline Seated Forward Bend, cm & Flexibility & 0 & 0 & 0 \\
\hline $\begin{array}{l}\text { Standing Long Jump Test (Broad } \\
\text { Jump), cm }\end{array}$ & Dynamic muscle strength of the lower limbs & 3,3 & 0 & 0 \\
\hline $1000 \mathrm{~m}$ run $(\mathrm{m} / \mathrm{sec})$ & General endurance & 18,7 & 1,7 & 5,3 \\
\hline
\end{tabular}

Note. $\mathrm{H}$ - hypersthenic; $\mathrm{N}$ - normosthenic ; A - asthenic body type.

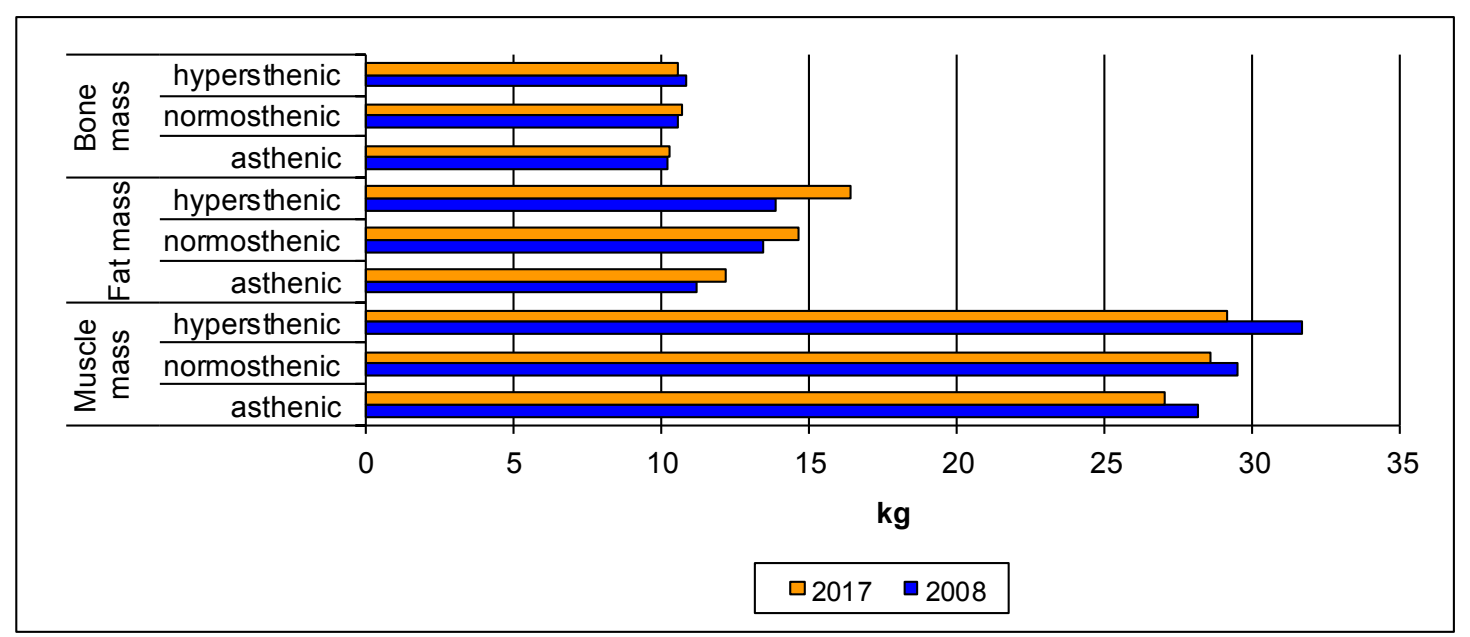

Fig. 2. The content of the main components in the body of young men of different generations and somatotypes

with the data of 2008, the decrease of MM is observed in hypersthenics in $7,9 \%$, in asthenic in $3,9 \%$, in normosthenics in 3,1\%.

The increase in FM of young men bodies (2017) was: $8,9 \%$ in asthenics, $8.8 \%$ in normosthenic , $16,3 \%$ in hypersthenic. The results of our study are consistent with the authors' data on the increase in absolute body weight, body mass index, and overweight among young men of Krasnoyarsk (Russia) [13].

The content of BM in young men bodies of Baikal region (Russia) with different somatotypes and different generations didn't change.

The decrease of the muscular component and increase of fat mass in students (2017) is an indirect confirmation of the physical inactivity growth among modern youth. The correlations between low motor activity and the increase in the content of fat mass in the body structure are indicated by surveys of young men and women aged 1522 years (Moscow, Russia) [50, 51]. In 2015, the World Health Organization determined: in European countries, there is a general downward trend in the level of physical activity of population; more than $70 \%$ of adolescents do not follow the recommendations for the motor regime [17]. This leads to a decrease in the overall indicator of the motor qualities of modern young people.

The comparative analysis of the results of examined young men (in 2008 and 2017) did not determine the significant changes in the indicators of systolic and diastolic blood pressure ( $\mathrm{p}>0.05)$.

The increase in the heart rate at rest was registered in 2017: in the hypersthenics group - in 3,9\%, in the normosthenics group - in 4,1\% $(p<0,05)$. In 2017 , the increase in heart rate and pulse recovery time after a physical load was registered: in hypersthenics - in 7,7\%, in normosthenics - by $5,7 \%$. The young men of hypersthenic and normosthenic body types (2017) had increase in the values of Robinson index. This testifies to decrease in the functional capabilities of the cardiovascular system of modern generation of young men. This is confirmed by the works of other researchers [53].

It is observed in young men with asthenic body type (2017) the decrease in heart rate at rest in $4,6 \%$ (p 
$<0.05)$ and heart rate after physical load (20 squats in $30 \mathrm{~s}$ ) in $6,0 \%$; reduction of recovery time after physical load by $14,3 \%$ and reduction of Robinson index value in $15,4 \%$. Our results in Robinson index do not contradict the work of other authors [54]. Such indicators indicate the economization of the cardiovascular system and the increased adaptation of the young men bodies with asthenic body type to physical loads. This is consistent with the results of students' research of Kazan (Russia) [55]. The authors showed that the phenomenon of bradycardia (decrease in heart rate) is a specific effect of endurance training. We defined that young men in Baikal region with asthenic body type were more enduring. The increase in the functional reserves of the cardiovascular system of young men (in the transition of somatotypes from hypersthenics to asthenics) is noted by the authors from Krasnoyarsk (Russia) [13].

It is known that the decrease in heart rate in strongbuild athletes is compensated by means of increasing the heart stroke volume. The lower is the heart rate at rest, the higher is the stroke volume [55]. We have not identified differences in the heart stroke volume indicators in young men of different generations and body types ( $p>0.05$ ). This is due to insufficient physical volume and intensity of physical activity in the classroom.

The strength of the hand's muscles refers to the indicators of a person's physical development [56]. The young men (2017) of all body types have lower strength indicators than young men $(2008)(\mathrm{p}<0.05)$.

The performed studies of the comparative analysis of motor qualities and the functional condition of young men allow to make the following recommendations:

1) In planning the educational process of physical education in young men with different somatotypes, it should apply physical culture and sports technologies aimed at the development of "lagging" motor qualities.
2) at the lessons of physical education of young men with hypersthenic somatotype, should pay more attention to sports and gaming technologies and cyclic endurance exercises (swimming, slow long-running, skiing). For normosthenics, it is recommended to increase the amount of exercise on the development of strength abilities. Young men with asthenic somatotype should pay more attention to the development of strength and flexibility.

3) To recommend to modern youth additional independent physical training and sports to compensate for their physical inactivity.

\section{Conclusions}

1. The young men aged 17-18 years old (born and living in Baikal region, Russia) of different generations and body types have distinctive significant indicators in a number of functional characteristics, motor abilities in body structure $(p<0.05)$. In recent years, there was an increase in the number of hypersthenics and a decrease in the number of asthenics.

2 . The young men (2017) have lower physical fitness indicators than young men (2008). The reason for the decrease in muscle and an increase in the fat component in modern young men with different somatotypes is hypodynamia.

3. Teachers of educational institutions of the discipline "Physical Education" should form a predictive database of screening observations on the development of morphofunctional and motor qualities of students with different body types. This will allow to correct the educational process of physical education with the application of integrative pedagogical and teaching methods.

\section{Conflict of interest.}

The authors declare that there is no conflict of interest.

\section{References}

1. Shtejnerdt SV, Achkasov EE. Dynamics of morphometric indicators of young men of different generations. International scientific-practical conference "Problems of modern human morphology". 25-27.09.2013. Moscow: RGUFKSMiT; 2013. P.152-153. (in Russian)

2. Isaev AP, Erlikh VV, Rybakov VV. Sport Training Individualization. State, Problems and Advanced Solutions. Nomos; 2018.

3. Kapilevich LV, Davlet'iarova KV, Koshel'skaia EV, Bredikhina IuP, Andreev VI. I. Physiological control methods in sport. Tomsk: Publishing House of Tomsk Polytechnic University; 2009. (in Russian)

4. Isaev AP, Erlikh VV, Romanov YN, BakharevaAS. Adaptation of athletes to middle-altitude conditions via the intensive development of local-regional muscular endurance and strength motor capability, stretching, and relaxation. Journal of Physical Education and Sport, 20016;16(4),194; 1219-1229. https://doi.org/10.7752/jpes.2016.04194

5. Golubeva GN, Golubev AI. Evaluation of cardiovascular system students' reaction on physical activity during the physical training. Sovremennye problemy nauki $i$ obrazovaniia, 2015; 1(1): 25-34. (in Russian)
6. Smelysheva LN, Kuznetsov AP. Blood serum digestive enzymes activity in persons with a different tone of the vegetative system under physical load. Human Sport Medicine. 2018;18(2):24-34. https://doi.org/10.14529/hsm180203

7. Mel'nikova OF, Lomakina NA. Physical activity as a health promotion factor. Uspekhi sovremennoj nauki i obrazovaniia, 2016;12(1): 153-155. (in Russian)

8. Sokolova IV, Chistiakova EV. The conditions to meet the deficit of motor activity as a factor in the preparation of students to pass the norms of the all-russian sports complex "ready for labor and defense». Sovremennye problemy nauki i obrazovaniia, 2018; 3: 56-62. (in Russian)

9. Burov AE, Erokhina OA, Nebratenko SV, Kuznecova GA. GTO as criterion of motive development of studen's youth. Sovremennye problemy nauki i obrazovaniia, 2016; 3: 78-85. (in Russian)

10.Kabachkova AV, Fomchenko VV, Frolova IuS. Students' physical activity. Vestnik Tomskogo gosudarstvennogo universiteta, 2015; 392: 175-178. DOI $10.17223 / 15617793 / 392 / 29$ (in Russian)

11. Sakharova IN, Efremova LV. Health of draftees from different regions of Russia. Izvestiia Penzenskogo gosudarstvennogo 
pedagogicheskogo universiteta im. V.G. Belinskogo, 2007; 5 (9): 39-44. (in Russian)

12.Svetlichkina, AA, Doroncev AV, Obukhova EV. Disturbance of the process of repolarization of the myocardium of the heart among students of the Astrakhan State Medical University, engaged in sports sections. Tendencii razvitiia psikhologii, pedagogiki i obrazovaniia, 2016; 1: 48-51. (in Russian)

13.Pulikov AS, Moskalenko OL. Adaptation possibilities young men of different body types, depending on age under conditions of Siberia. Sovremennye problemy nauki $i$ obrazovaniia, 2016; 4: 101-107. (in Russian)

14.Aslon'ianc AM, Nefedova LV, Nefedov PV. On adaptive potential as one of the indicators of the health of medical college students. Vestnik novykh medicinskikh tekhnologij, 2007; 14(4): 84-86. (in Russian)

15.Isaev AP, Abzalilov RYa, Rybakov VV, Nenasheva AV, Korableva YuB. Modeling in the system of adaptation and sport training management. Human. Sport. Medicine. 2017; 16(2), 42-51. https://doi.org/10.14529/hsm160204

16.Pulikov AS, Moskalenko OL. Dynamics of weight and body density depending on the constitution, sexual dimorphism and age of young men in the conditions of city anthropotechnogenic pollution. Mezhdunarodnyj zhurnal prikladnykh i fundamental'nykh issledovanij, 2014; 8(3): 7780. (in Russian)

17.WHO Fact Sheet - Physical Activity: Global recommendations on physical activity for health. [Internet] 2017 Nov 1 [updated 2018 Jan 1; cited 2018 Nov 8]. Available from: http://www.euro.who.int/_data/assets/pdf file/0005/288041/WHO-Fact-Sheet-PA-2015.pdf?ua=1

18.Gerdin G, Pringle R. The politics of pleasure: an ethnographic examination exploring the dominance of the multi-activity sport-based physical education model. Sport Education and Society. 2017;22(2):194-213. https://doi.org/10.1080/13573322.2015.1019448

19.Basset D, Fitzhugh E, Heaz G, Erwin P, Frederick G, Wolff D. Estimated energy expenditures for schoolbased policies and active living. American Journal of Preventive Medicine, 2013; 44(2): 108-113. https://doi.org/10.1016/j.amepre.2012.10.017

20.Manolachi V, Budevici-Puiu L. The insurance and evaluation of the scientific research quality within the institution of higher education of physical training and sport from republic of Moldova. Quality - Access to Success, 2016; 17(150): 6567.

21.Manolachi V. "Personality Deficit" - a Dangerous Disease of Contemporary Society and the Role of Sport in Combating It. Revista Romaneasca pentru Educatie Multidimensionala, $2018 \quad$ 10(1), 4-9. https://doi.org/10.18662/rrem/11

22.Iacun SM, Luneva NV, Sokolova IA. Analysis of the dynamics of morbidity and health of students of the Kursk State University. Medicina i Farmaciia, 2017; 3(3). https://doi.org/10.18413/2313-8955-2017-3-3-57-64

23.Zalyapin VI, Isaev AP, Erlikh VV, Gainullin RA. Statistical analysis of the functional status of the students. Bulletin of the South Ural State University Series-Mathematical Modelling Programming \& Computer Software. 2016;9(4):96-104. https://doi.org/10.14529/mmp160409

24.Katzmarzyk PT, Lee IM, Martin CK, Blair SN. Epidemiology of Physical Activity and Exercise Training in the United States. Progress in Cardiovascular Diseases. 2017;60(1):3-10. https://doi.org/10.1016/j.pcad.2017.01.004

25.Shin DW, Yun JM, Shin JH, Kwon H, Min HY, Joh
HK, et al. Enhancing Physical Activity and Reducing Obesity Through Smartcare and Financial Incentives: A Pilot Randomized Trial. Obesity. 2017;25(2):302-310. https://doi.org/10.1002/oby.21731

26.Talović M, Mahmutović I, Jelešković E, Sedić D, Alić H, Lakota R, et al. Quantitative changes of specific motor abilities of students under the influence of regular and additional activitiesin sport and physical education. International scientific journal of kinesiology, 2015; 8: 3437.

27. Sokolov AIa, Sukhanova IV. Indicators of physical development and cardiorespiratory system in students, depending on the particular physique. Valeologiia, 2006; 1: 46-50. (in Russian)

28.Lobanov IuIa, Kovalenko VN, Mironova OV, Tokareva AV. The nature of the manifestation of physical qualities, depending on the typological features of the constitution of students. Uchenye zapiski universiteta imeni P.F. Lesgafta, 2018; 2(156): 122-126. (in Russian)

29.Koshkin EV. Individually-typological features of cadets of different somatotypes. Uchenye zapiski universiteta imeni P.F. Lesgafta, 2014; 4 (146): 94-98. (in Russian)

30.Kolokoltsev MM. Characteristic of locomotor abilities of male students of different constitutional types. Vestnik IrGTU, 2015; 10 (105): 309 -314. (in Russian)

31.Kolokoltsev MM. Characteristics of the motor capabilities of students-young men with different types of constitution. Vestnik IrGTU, 2014; 11(94): 338-343. (in Russian)

32. Orlova SV. Evaluation of the health status of students of adolescence, taking into account somatotypes. [PhD thesis]. Rostov-on-Don; 2014. (in Russian)

33. Chwalczynska A, Jedrzejewski G, Socha M, Jonak W, Sobiech KA.Physicalfitness of secondary schooladolescents in relation to the body weight and the body composition: classification according to World Health Organization. Part I. Journal of Sports Medicine and Physical Fitness. 2017;57(3):244-251. https://doi.org/10.23736/s0022-4707.16.05664-4

34.Martens J, Figueiredo P, Daly D. Electromyography in the four competitive swimming strokes: A systematic review. Journal of Electromyography and Kinesiology, 2015; 25(2): 273-291. (in Russian)

35.Davydova OS, Bogdanovskij AN. Factors determining the need for speed-strength development in young basketball players, considering their somatotypes. Uchenye zapiski universiteta imeni P.F. Lesgafta, 2018; 2(156): 51-54. (in Russian)

36.Bakhareva AS, Isaev AP, Erlikh VV, Aminov AS. Hydrostatic pressure as a factor of effective adaptation and improved sport performance of ski racers. Gazz Med Ital - Arch Sci Med, 2018;177(3 Suppl 1):30-9. https://doi.org/10.23736/S0393-3660.17.03724-X

37.Kochenkov VB, Shestakov MM. Features of the physical fitness of conscripts of different somatic types. Uchenye zapiski universiteta imeni P.F. Lesgafta, 2018; 2(156): 114118. (in Russian)

38.Musikhina EA. Integrated research of Irkutsk region natural system. Uspekhi sovremennogo estestvoznaniia, 2012; 2: 3134. (in Russian)

39.Khanygin IV. Hygienic estimation of radiative situation in Irkutsk region. Sibirskij medicinskij zhurnal, 2010; 5: 116119. (in Russian)

40.WMA Declaration of Helsinki - Ethical Principles for Medical Research Involving Human Subjects. [Internet] 2013 Nov 1 [updated 2017 Jan 1; cited 2018 Nov 8]. Available from: http://www.ub.edu/recerca/Bioetica/doc/Declaracio Helsinki_2013.pdf 
41.International Standards for Anthropometric Assessment. [Internet] 2000 Nov 1 [updated 2001 Jan 1; cited 2018 Nov 8]. Available from: http://www.ceap.br/material/MAT17032011184632.pdf

42.Fefelova VV, Koloskova TP, Fefelova YA, Kazakova TV, Sergeeva EY. Effect of food load on activities of enzymes of the main metabolic pathways in blood lymphocytes in girls with different anthropometric parameters. Bulletin of Experimental Biology and Medicine. 2015; 159(3): 309-313.

43. Matiegka J. The testing of physical efficiency. Am. J. Phys. Anthropol. 1921; 4(3): 223-230.

44.Robinson BF. Relation of heart rate and systolic blood pressure to the onset of pain in angina pectoris. Circulation. 1967; 35: 1073-1083.

45.Nikitina OS, Yevsey AV, Narezkina LP, Pereverzev VA. Normal physiology. Minsk. BSMU; 2016.

46.Council of Europe. Testing physical fitness: Eurofit experimental battery - provisional handbook. [Internet] June 28,2011 [updated2012 Jan 1; cited2018Nov8].Availablefrom: http://www.bitworks-engineering.co.uk/linked/eurofit $\% 20$ provisional $\% 20$ handbook $\% 20$ leger $\% 20$ beep $\% 20$ test $\% 20$ 1983.pdf

47.PCFSN. The president's challenge: Physical fitness test. [Internet] July 14, 2011 [updated 2012 Jan 1; cited 2018 Nov 8]. Available from: https://www .presidentschallenge.org/challenge/physical/ index.shtml

48.Zajceva VV, Son'kin VD, Burchik MV, Maslova GM, Fil'chenkov DA, Tiunova OV. Differentiated assessment of the development of motility in young men of different body types. Sbornik nauchnykh trudov VNIIFK, 1996; 2: 29-39. (in Russian)

49.Džibrić D, Hrnjić J, Bašinac I. Comparing basic-motor capabilities of students in higher grades of primary school.
Sport Science Intenational Scientific Journal of Kinesiology, 2017; 1: 113- 117.

50.Matosian KA, Oranskaia A N, Pustovalov DA, Cherepkova EV, Skotnikova IuV, Burdiukova EV, Anishchenko AP, Gurevich KG, Khanfer'ian RA. Features of the qualitative content of fat tissue in the body at pubertal and postpubertal age, considering age, gender, level of physical activity and diet. Voprosy pitaniia. 2015; 5: 88-94. (in Russian)

51.Iampol'skaia IuA, Zubareva VV, Khomiakova IA, Permiakova EIu. Physical development of schoolchildren and the demographic situation. International scientific-practical conference "Problems of modern human morphology". 2527.09.2013. Moscow: RGUFKSMiT; 2013. P. 155-156. (in Russian)

52.Sokol'skaia TI, Maksimenko VB, Gulin AV. Gender and age features of physical development and components of body mass of persons with adiposity. Vestnik Tambovskogo universiteta, 2010; 15(2): 669-672. (in Russian)

53.Petlenko VP. Basics of Valeology. 1998. (in Russian)

54. Sharypova NV, Sveshnikov AA. Somatotype influence to adaptive reactions of body in examinational stress. Sovremennye problemy nauki i obrazovaniia. 2007; 6: 5964. (in Russian)

55.Sviatova NV, Urbanov AIu, Miftakhov SF, Abdulin IF. Functional possibilities of organism of students in connection with classes exercise aimed at developing endurance. Sovremennye problemy nauki i obrazovaniia. 2018; 1: 45-55. (in Russian)

56.Price AA, Whitt-Glover MC, Kraus CL, McKenzie MJ. Body Composition, Fitness Status, and Health Behaviors Upon Entering College: An Examination of Female College Students From Diverse Populations. Clinical Medicine Insights-Womens Health. 2016;9:23-29. https://doi.org/10.4137/cmwh.s34697

Information about the authors:

Kolokoltsev M.M. (Corresponding author); http://orcid.org/0000-0001-6620-6296; mihm49@mail.ru; Irkutsk National Research Technical University; ul. Lermontov 83, Irkutsk, 664074, Russia.

lermakov S.S.; http://orcid.org/0000-0002-5039-4517; sportart@gmail.com; Department of Tourism and Recreation, Gdansk University of Physical Education and Sport; Kazimierza Górskiego 1, 80-336 Gdańsk, Poland.

Jagiello M.; http://orcid.org/0000-0001-5591-4537; wjagiello1@wp.pl; Department of Theory of Sport and Human Motority, Gdansk University of Physical Education and Sport; Kazimierza Górskiego 1, 80-336 Gdańsk, Poland.

Cite this article as: Kolokoltsev MM, Iermakov SS, Jagiello M. Comparative analysis of the functional characteristics and motor qualities of students of different generations and body types. Pedagogics, psychology, medical-biological problems of physical training and sports, 2018;22(6):287-294. https://doi.org/10.15561/18189172.2018.0602

The electronic version of this article is the complete one and can be found online at: http://www.sportpedagogy.org.ua/index.php/PPS/issue/archive

This is an Open Access article distributed under the terms of the Creative Commons Attribution License, which permits unrestricted use, distribution, and reproduction in any medium, provided the original work is properly cited (http://creativecommons.org/licenses/by/4.0/deed.en).

Received: 19.10 .2018

Accepted: 24.11.2018; Published: 22.12.2018 